\title{
Conflict, Conflict Resolution and Marital Quality
}

\author{
Adriana Wagner ${ }^{1}$ (D) https://orcid.org/0000-0002-0629-2310 \\ Clarisse Pereira Mosmann² (D) https://orcid.org/0000-0002-9275-1105 \\ Patrícia Scheeren ${ }^{3}$ (D) https://orcid.org/0000-0002-9829-278X \\ Daniela Centenaro Levandowski ${ }^{4}$ (D) https://orcid.org/0000-0002-6338-7287
}

\begin{abstract}
Studies on conflict and marital quality are important for clinical practice involving couples. We analyzed the predictive power of motives and conflict resolution styles on marital quality in a sample from Southern Brazil. The following were applied to 750 men and 750 women aged 40 years old on average $(S D=11.07)$ : sociodemographic data sheet, Marital Conflict Scale, Conflict Resolution Style Inventory and The Golombok Rust Inventory of Marital State. Marital quality was associated with how the couples solve their conflicts and the reasons for which they discuss. The use of constructive conflict resolution strategies was a predictor of marital quality, as were the motives related to financial issues, household chores, and time spent together. The results reveal the importance of the professionals paying attention to the nature of the marital conflicts reported by the couples and the strategies employed to solve them as factors involved in the evaluation of marital quality.
\end{abstract}

Keywords: conflict, marriage, health promotion

\section{Conflito, Estratégias de Resolução e Qualidade Conjugal}

Resumo: Estudos sobre conflito e qualidade conjugal são importantes para a prática clínica com casais. Analisou-se o poder preditivo dos motivos e estilos de resolução de conflito sobre a qualidade conjugal em uma amostra do sul do Brasil. Foram aplicados em 750 homens e 750 mulheres com idade média de 40 anos $(S D=11.07)$ : ficha de dados sociodemográficos, Marital Conflict Scale, Conflict Resolution Style Inventory e The Golombok Rust Inventory of Marital State. A qualidade conjugal associou-se à forma como os casais resolvem seus conflitos e aos motivos pelos quais discutem. O uso de estratégias construtivas de resolução de conflito foi preditor da qualidade conjugal, assim como os motivos relacionados às questões financeiras, tarefas domésticas e tempo juntos. Os resultados revelam a importância dos profissionais atentarem para a natureza dos conflitos conjugais reportados pelos casais e as estratégias empregadas para resolvê-los como fatores implicados na avaliação da qualidade conjugal.

Palavras-chave: conflito, casamento, promoção da saúde

\section{Conflicto, Estrategias de Resolución y Calidad Conyugal}

Resumen: Son importantes los estudios sobre conflicto y calidad conyugal en la práctica clínica con parejas. Se analizó el poder predictivo de los motivos y estilos de resolución de conflictos sobre la calidad conyugal en una muestra de la región Sur de Brasil. Se aplicó a 750 hombres y a 750 mujeres con un promedio de edad de 40 años $(S D=11.07)$ la ficha de datos sociodemográficos Marital Conflict Scale, Conflict Resolution Style Inventory y The Golombok Rust Inventory of Marital State. La calidad conyugal se asoció con el modo con el cual las parejas resuelven sus conflictos y con sus motivos de discusión. El uso de estrategias constructivas de resolución de conflictos fue el predictor de la calidad conyugal, así como los motivos relacionados con las cuestiones financieras, las tareas domésticas y el tiempo juntos. Los resultados apuntan la importancia de que los profesionales tengan en cuenta la naturaleza de los conflictos conyugales reportados por las parejas y las estrategias utilizadas para resolverlos como los factores implicados en la evaluación de la calidad conyugal.

Palabras clave: conflicto, matrimonio, promoción de la salud

${ }^{1}$ Universidade Federal do Rio Grande do Sul, Porto Alegre-RS, Brazil

${ }^{2}$ Universidade do Vale do Rio dos Sinos, São Leopoldo-RS, Brazil

${ }^{3}$ Faculdade INEDI-CESUCA, Cachoeirinha-RS, Brazil

${ }^{4}$ Universidade Federal de Ciências da Saúde de Porto Alegre, Porto Alegre-RS, Brazil

Support: This article stems from a larger reserch project entitled "Mapeamento e Intervenção nas Relações Conjugais no RS: Questões de Gênero, Resolução de Conflitos e Violência", founded by FAPERGS and CNPq, Edital PRONEX (Programas de Excelência em Pesquisa) 008/2009 (Processo número 10/00588).

Correspondence address: Adriana Wagner. Universidade Federal do Rio Grande do Sul. Instituto de Psicologia. Rua Ramiro Barcelos, 2600, Sala: 226, Porto Alegre-RS, Brazil. CEP 90.040-060. E-mail: adrianaxwagner@gmail.com
Intimate relationships, such as marriage, are an important part of adult life, and have a direct impact on mental (Norgren, Souza, Kaslow, Hammerschmidt, \& Sharlin, 2004), physical (Kiecolt-Glaser et al., 2015) and occupational health (Scorsolini-Comin, Fontaine, Barroso, \& Santos, 2016; Whisman, Dementyeva, Baucom, \& Bulik, 2012), as well as on the quality of family life (Stroud, Meyers, Wilson, \& Durbin, 2015). A significant portion of the Brazilian and international literature has focused on the study of marital quality (Askari, Noah, Hassan, \& Baba, 2012; Scheeren, Vieira, Goulart, \& Wagner, 2014), which, in the 
present study, is defined as the degree of satisfaction, trust, respect and shared interests between the two partners in a marriage (Falcke, Wagner, \& Mosmann, 2008; Rust, Bennun, Crowe, \& Golombok, 2010).

Marital quality is determined by the dynamic interactions between the members of a couple (Mosmann, Wagner, \& FéresCarneiro, 2006), and given its complexity, has been found to be a particularly difficult concept to measure. This complexity is related to its susceptibility to being influenced by the personality traits, personal values, sexuality, educational level, sociocultural and socioeconomic status of the partners in a marriage, as well as by the presence of children, each individual's occupational life and their past relationship experiences (Olson, 2000).

Several researchers have sought to identify and understand the variables that influence marital quality and determine the way in which these factors are associated with satisfactory relationships. A study conducted with 38 upper middle-class Brazilian couples who had been married for an average of 29 years, and ranged in age from 42 to 73 years old, found that closeness, cohesion and adequate problem-solving and communication strategies were the main predictors of marital satisfaction (Norgren et al., 2004). This study also reported that marital satisfaction was associated with satisfaction with one's socioeconomic status and shared religious values.

Birditt, Brown, Orbuch, and McIlvane (2010) performed a similar study in a different cultural context, and evaluated marital quality in a sample of 373 North-American couples. The authors found that both marital quality and stability were associated with the problem-solving strategies employed by each couple. These strategies consist of interpersonal behaviors involved in the management of marital conflicts (Gottman, 1994). Kurdek (1994b) suggested that these styles of conflict resolution could be classified into the following four categories: positive, withdrawal, compliance, and conflict engagement.

Positive resolution styles consist of constructive ways to resolve disagreements, in which individuals are able to negotiate and compromise on solutions which benefit both partners. Withdrawal involves long periods of silence and refusal to discuss the problems at hand, causing individuals to appear distant and uninterested. Compliance is characterized by the acceptance of any solutions offered so as to avoid further discussion, before each member of the couple can present their opinion or defend their point of view. Lastly, conflict engagement involves personal attacks, insults and loss of emotional and/or behavioral control (Kurdek, 1994b).

Studies conducted over the past decade corroborate the association between conflict management styles and levels of marital quality (Dush \& Taylor, 2012; McNulty \& Russell, 2010; Papp, Goeke-Morey, \& Cummings, 2007; Ridley, Wilhelm, \& Surra, 2001; Scheeren et al., 2014; VeldoraleBrogan, Lambert, Fincham, \& DeWall, 2013). Positive conflict resolution strategies have been found to contribute to happiness and marital satisfaction in couples from several different cultural backgrounds (Dush \& Taylor, 2012; Leggett, Roberts-Pittman, Byczek, \& Morse, 2012; Ridley et al., 2001; Scheeren et al., 2014). For instance, a study conducted with 735 married Chinese women revealed that those who reported higher relationship quality believed that marital problems could be solved and should not be avoided (Dong \& Li, 2007). A study conducted in Iran also revealed that the enhancement of communication and problem-solving skills may have a positive impact on marriage quality by helping individuals to overcome marital conflicts (Askari et al., 2012).

Studies have also found associations between marital dissatisfaction and the use of inadequate conflict management strategies (Leggett et al., 2012). Unhappy couples tend to make greater use of negative problem-solving strategies in the beginning of their relationships (McNulty \& Russell, 2010). A North-American study conducted by Ridley et al. (2001) showed that couples in which one of the partners constantly withdrew from conflicts reported lower marital quality. Therefore, couples who make use of negative problem-solving strategies may also report lower rates of marital satisfaction.

In the $1990 \mathrm{~s}$, studies on marital conflict focused mostly on the way in which couples managed conflicts (Gottman, 1994) rather than on the reasons for the conflicts themselves. However, recent studies have shown that the impact of marital conflicts on relationship quality is intimately associated with the topics being discussed and how they are perceived by the partners (Williamson, Hanna, Lavner, Bradbury, \& Karney, 2013). Topics considered to be very important by the couple may be more difficult to discuss, and are more likely to trigger inadequate communication patterns (Colossi \& Falcke, 2013; Rauer, Williams, \& Jensen, 2015).

So as to better understand the influence of marital conflict themes on relationship quality, Kurdek (1994a) performed a study in which a sample of 75 homosexual men, 51 homosexual women and 108 heterosexual couples with no children were asked to identify twenty topics of marital disagreement. Based on these topics, the researchers identified six main reasons for marital conflicts: power (excessive demands or possessiveness, lack of equality in the relationship, personal insults), social issues (politics and social issues, personal values, parents), personal flaws (drinking or smoking, personal grooming and driving style), distrust (previous lovers, distrust or lying), intimacy (sex and lack of affection) and personal distance (job or school commitments, frequent physical absence). This study found an overall negative correlation between marital satisfaction and the frequency of disagreements between partners. However, the reasons for the conflicts themselves also had an important impact on marital quality. More specifically, conflicts about power and intimacy tended to have a more negative impact on marital relationships than discussions about personal problems, plans, distance and distrust.

A North-American study investigated the frequency with which 100 couples discussed money matters, which were thought to be among the most stressful themes of marital conflict, and the way in which these conflicts were usually solved (Papp, Cummings, \& Goeke-Morey, 2009). This information was to be registered by each couple, who was instructed to keep a record of the themes of any conflicts occurring over the course of 15 days. The results of the study suggested that the most frequently discussed topics were children, followed by domestic chores, 
Wagner, A., Mosmann, C. P., Scheeren, P., \& Levandowski, D. C. (2019). Marriage and Conflict Resolution.

communication and leisure activities. Money was the sixth most common topic of discussion for men, and the fifth most common for women. However, these findings suggested that, although money was not the most frequently reported reason for marital conflict, discussions regarding financial issues were more stressful, threatening, long-drawn, recurring and difficult to resolve, and more likely to lead to increased anger and depression when compared to discussions regarding other topics. Similar data were found in a study conducted in Brazil by Costa, Falcke, and Mosmann (2015), with 200 married individuals. The main reasons for marital conflict identified were children, experiences in the families of origin, money, differences of personal characteristics, preferences of each partner and time spent together.

Another North-American study conducted by Williamson et al. (2013) with 431 couples also suggested that closeness was among the most difficult issues to discuss in marital relationships. The least difficult topics of discussion for women were found to be planning and decision making, while men found that discussions about children were the least difficult. The couples assessed in the study also reported a high frequency of discussions about household chores, and a slightly lower frequency of discussions about friends. Unlike other studies in the literature, this investigation did not find any associations between marital satisfaction and the themes of marital conflict.

The association between marital conflicts and sexuality has also been extensively studied in the literature. According to a Canadian study with 15 newlywed couples, sexual issues are a constant theme of discussion in many marriages, and may have a significant impact on these relationships (Rehman et al., 2011). In a study with 100 North-American couples, $29 \%$ of the men and $31 \%$ of the women identified sexual issues as an important theme of marital discord. In these couples, discussions regarding sexuality were found to be conflict-ridden, recurring, but very important for the partners involved (Papp, GoekeMorey, \& Cummings, 2013).

Studies have also investigated the impact of conflict resolution strategies on the routine, as well as the physical and psychological functioning of married couples (Kiecolt-Glaser, Gouin, \& Hantsoo, 2010). Positive conflict resolution strategies have not been found to be associated with the presence of psychological disorders, although the latter do appear to be more frequent in couples who make greater use of negative conflict resolution strategies (Papp et al., 2007). More specifically, in women, psychological symptoms have been found to be associated with a high frequency of withdrawal from marital conflict, while in men, in addition to being related to withdrawal, psychiatric symptoms also tend to be associated with high levels of negativity, anger and sadness (Papp et al., 2007).

Similarly, an American longitudinal study that assessed 373 newlywed couples for 16 years suggested that negative conflict resolution behaviors in both men and women, such as screaming at or criticizing one's partner, may be predictive of the likelihood of divorce (Birditt et al., 2010). Mosmann et al. (2006) found that marital dissatisfaction and divorce may both be caused by an inability to overcome crises. That is, couples who do not have the resources to overcome and adapt to stressful situations may be more vulnerable to divorce. Conversely, the use of positive conflict resolution strategies may lead to increased marital satisfaction and stability (Birditt et al., 2010).

Although most studies on marital conflict tend to focus on the negative aspects of conflict resolution, some of them have also investigated the predictive role of positive emotions in marital satisfaction (Ben-Naim, Hirschberger, Ein-Dor, \& Mikulincer, 2013; Graber, Laurenceau, Miga, Chango, \& Coan, 2011). For instance, a four-year longitudinal study conducted with 172 North-American couples revealed that an interaction between conflict-solving abilities and positive affect during a conflict resolution task was predictive of changes in marital satisfaction over this period (Johnson et al., 2005). These findings suggest that positive affect may have a protective role in marital satisfaction even for couples with poor problem-solving skills (Graber et al., 2011).

In Brazil, the association between marital conflict and marital quality was also studied. An investigation with 214 couples aimed to analyze the role of conflict resolution styles as mediators between types of attachment and marital quality (Scheeren et al., 2014). The results indicated that the styles of conflict resolution (positive problem solving, conflict engagement, withdrawal and compliance) mediate the relationship between attachment and marital quality. These findings suggest the importance of expanding the couples' repertoire of positive conflict resolution strategies for the promotion of marital quality (Scheeren et al., 2014; Sierau \& Herzberg, 2012).

Although this research has clear implications for clinical practice involving couples and the understanding of intimate and personal relationships, there is a pronounced lack of studies on marital quality and conflict in the Brazilian population (Costa et al., 2015). The few studies available on these topics have identified correlations between positive problem-solving strategies and marital satisfaction, and, conversely, between negative strategies and marital dissatisfaction. However, these studies have not been able to ascertain whether specific behaviors and styles of conflict may have a more significant impact on marital quality. These studies have also failed to discuss the nature of the relationships between these factors and between the reasons for conflict and marital quality, as well as the association between the reasons for conflict and conflict resolution styles and its impact on marital quality. The understanding of these phenomena is further complicated by the wide variability in the way these constructs are assessed in the international literature. The lack of a standardized vocabulary to discuss conflict resolution styles and marital quality has also contributed to the existing gap between research and clinical practice involving couples.

In light of these observations, the present study aimed to contribute to the current knowledge about the relationship dynamics of Brazilian couples by assessing the predictive power of marital discussion themes and conflict resolution styles in relation to marital quality in a sample of men and women from the South of Brazil. The hypothesis 
of the study was that constructive conflict resolution strategies had a positive impact on marital quality, while destructive conflict resolution strategies had a negative impact. Likewise, conflicts motivated by money and childrearing (parenting) reasons were expected to be associated with lower levels of marital quality in the sample studied.

\section{Method}

\section{Study design}

Descriptive and exploratory study, with a cross-sectional quantitative design.

\section{Participants}

Couples $(n=750)$ recruited from different regions of the state of Rio Grande do Sul in Brazil participated in the study. At least six months of cohabitation was required for inclusion. Sixty-nine percent of the participants were married, while $31 \%$ were in common-law unions. Eighty-five percent were in their first marriage, while the remaining $15 \%$ had been previously married. The length of the participants' relationship ranged from 6 months to 51 years $(M=15.78 ; S D=10.40)$. The youngest participants were 18 years old, while the oldest were 80 years old $(\mathrm{M}=40.90 ; \mathrm{SD}=11.07)$. Further data regarding the sample's characteristics can be found in Table 1 .

Table 1

Sample's characteristics

\begin{tabular}{|c|c|c|c|}
\hline Variables & & $n$ & $\%$ \\
\hline \multirow[t]{2}{*}{ Marital status } & Married & 1035 & 69 \\
\hline & Common-law & 465 & 31 \\
\hline \multirow[t]{2}{*}{ Children } & Yes & 1182 & 78.8 \\
\hline & No & 318 & 21.2 \\
\hline \multirow[t]{9}{*}{ Education } & No formal education & 03 & 0.2 \\
\hline & Incomplete primary education & 136 & 9.1 \\
\hline & Complete primary education & 106 & 7.1 \\
\hline & Incomplete secondary education & 98 & 6.6 \\
\hline & Complete secondary education & 340 & 22.7 \\
\hline & Incomplete undergraduate education & 249 & 16.7 \\
\hline & Complete undergraduate education & 245 & 16.4 \\
\hline & Incomplete graduate education & 47 & 3.1 \\
\hline & Complete graduate education & 271 & 18.1 \\
\hline \multirow{2}{*}{ Work outside the home } & No & 289 & 19.5 \\
\hline & Yes & 1192 & 80.5 \\
\hline \multirow[t]{5}{*}{ Income } & No personal income & 136 & 9.3 \\
\hline & 1 to 3 minimum wages & 638 & 43.5 \\
\hline & 4 to 6 minimum wages & 341 & 23.3 \\
\hline & 7 to 9 minimum wages & 113 & 7.7 \\
\hline & 10 or more minimum wages & 238 & 16.2 \\
\hline
\end{tabular}

\section{Instruments}

A four-part assessment instrument was administered to all participants. Each variable of interest was assessed as follows:

Sociodemographic profile. Evaluated by an inventory developed for the present study, containing 16 closed questions regarding sociodemographic characteristics.

Marital quality. The Golombok Rust Inventory of Marital State - GRIMS (Rust, Bennun, Crowe, \& Golombok, 1988), translated and adapted to Brazilian Portuguese by Falcke et al., 2008), which contains 28 items scored on a 4-point Likert scale (strongly disagree, disagree, agree and strongly agree), was employed. GRIMS assesses the following dimensions of marital quality: satisfaction, communication, shared interests, trust and respect. Higher scores on the scale are indicative of greater marital quality. In the present study, the instrument was found to have a reliability coefficient of .88 .

Marital conflict. Evaluated by the Marital Conflict Scale (Buehler \& Gerard, 2002; translated and adapted to Brazilian Portuguese by Mosmann \& Wagner, 2008), an instrument that consists of nine items comprising two separate subscales. The "disagreements" subscale contains six items, which are scored on a six-point Likert scale (never, once a month 
Wagner, A., Mosmann, C. P., Scheeren, P., \& Levandowski, D. C. (2019). Marriage and Conflict Resolution.

or less, many times a month, approximately once a week, many times a week, almost every day) for evaluation of the frequency with which the individuals experienced discussions with their partners over the previous year. The "arguing and hitting" subscale contains three items, scored on a similar five-point Likert scale (never, rarely, sometimes, frequently, and always). Item two of the latter subscale is reverse-coded and measures the frequency of calm discussions, while items one and three assess the frequency of arguments and physical violence between husband and wife. Higher scores on this item suggest greater marital conflict. The present study found a Cronbach's alpha of .71 for the first subscale, and an alpha of .61 for the second subscale. In a previous study, the Brazilian version of this instrument was reported to have a Cronbach's alpha of .71.

Conflict resolution strategies. Evaluated by the Conflict Resolution Style Inventory (CRSI) (Kurdek, 1994b; translated and adapted to Brazilian Portuguese by Delatorre, Scheeren, \& Wagner, 2017), an instrument that contains 16 items which are scored on a five-point Likert scale (never, rarely, occasionally, frequently, always). CRSI investigates the conflict resolution strategies employed by each couple, classifying them into four categories: positive problemsolving, conflict engagement, withdrawal and compliance. The scores on each subscale are added up to provide four scores ranging from four to 25 , depending on the number of items in each domain. A mean value can then be calculated for each subscale. In the present study, the conflict engagement subscale was found to have a Cronbach's alpha of .77, while the positive problem-solving dimension had an alpha of .75 . The withdrawal and compliance dimensions had alpha values of .61 and .53 , respectively.

\section{Procedures}

Data collection. Data was collected in 67 municipalities in the state of Rio Grande do Sul by researchers from seven different universities. All participants signed an informed consent form prior to their inclusion in the study. The individuals were selected by convenience sampling and recommended other participants for the study, resulting in a "snowball" sampling effect. Each individual was provided with an envelope containing the informed consent form and the assessment instruments, which were filled in by the participants at their convenience. To evaluate the semantic adaptation of the research protocol, a pilot study with 50 subjects was conducted, and the necessary modifications for a better understanding of the questions used in data collection was developed.

Data analysis. The collected data were tabulated on the SPSS software (version 21). The responses were analyzed to assess the frequencies, means and standard deviations of the reasons for marital conflict and levels of marital quality. The Pearson Correlation Coefficient and Multiple Linear Regression were used in subsequent analyses. The Multiple Linear Regression was performed according to the Stepwise method. The GRIMS score was the dependent variable and all the four CRSI dimensions and the nine items of the Marital Conflict Scale were independent variables. Data normality, independent errors and homoscedasticity were estimated for the analysis. The missing values were treated via multiple linear regression.

\section{Ethical Considerations}

This study was conducted according to the guidelines proposed by the Brazilian legislation based on National Health Council Resolution 196/96, effective at the time of data collection, and on Resolution 16/2000 of the Brazilian Federal Council of Psychology. This study received approval from the Ethics Committee of the Federal University of Rio Grande do Sul in October 2009 (Protocol 2009/040).

\section{Results}

Descriptive analyses were performed to assess the frequencies, means and standard deviations of the variables measured. Of the main reasons for marital conflict reported by the participants, "Time spent together" $(M=3.14$; $\mathrm{SD}=2.08)$ appeared to be the most frequent reason for conflict, while discussions regarding children $(M=2.35 ; \mathrm{SD}=21.63)$, domestic chores $(M=2.33 ; S D=1,54)$ and sex $(M=2.32$; $\mathrm{SD}=1.45$ ) occurred less often, although with similar frequencies. Financial issues $(M=1.88 ; S D=1.18)$ were among the least frequently reported causes of conflict. The least frequent cause was legal issues $(M=1.43 ; \mathrm{SD}=.98)$.

The participants reported varying levels of marital quality, ranging from very good levels to the presence of very severe relationships problems. A total of $13.5 \%$ of the participants reported poor marital quality, while $5.0 \%$ of the individuals had very severe relationship problems. On the other hand, $9.9 \%$ of the participants classified their marital quality as "very good", and a total of $17.3 \%$ of the participants reported average marital quality. In relation to the conflict resolution strategies, problem solving was the main strategy reported by the participants $(M=14.45$; $\mathrm{SD}=3.14)$, followed by compliance $(M=9.86 ; S D=2.64)$, withdrawal $(\mathrm{M}=8.85 ; \mathrm{SD}=2.88)$, and the least frequent strategy was conflict engagement $(\mathrm{M}=7.73 ; \mathrm{SD}=2.87)$.

Regarding the correlation between the aforementioned variables, the results shows that all variables were significantly correlated among themselves, although to a weak degree (results between $r=-.03$ to .39 ). Only the theme of conflict "sex" had a moderate correlation $(r=.61)$.

The reasons for marital conflict and the conflict resolution styles used by the participants were then included as predictors in a multiple linear regression model, so as to identify the power of these variables for the prediction of marital quality. All independent variables (reasons for conflict and CRSI dimensions) were simultaneously included in the model. The final regression model was able to explain $38.7 \%$ of the variance in the marital quality reported $\left(R^{2}=.387\right)$. The Durbin-Watson statistic's value was 1.796 . 
Seven variables were included in the final model (reasons for conflict and CRSI dimensions). Table 2 displays the variables that were included in the model. Of these seven variables, only one had a positive impact on marital quality: CRSI's positive problem-solving variable $(\beta=.285, p<.001)$, which was the most significant predictor of good marital quality. CRSI's conflict engagement variable $(\beta=-.174, p<.001)$ was the one that contributed most negatively to marital quality, followed by CRSI's withdrawal $(\beta=-.144, p<.001)$ and compliance $(\beta=-.106, p<.001)$ variables. Of the reasons for marital conflict included in the model, "Financial issues" $(\beta=-.140, p<.001)$ had the greatest negative influence on marital quality, followed by "Domestic chores" $(\beta=-.135, p<.001)$ and "Time spent together" $(\beta=-.070, p=.007)$.

Table 2

Standardized Beta Coefficients, $t$-Values and Unstandardized Beta Coefficients for Predictors of Marital Quality

\begin{tabular}{lcccc}
\hline Variable & $\mathrm{B}$ & $t$ value & $\beta$ & \multicolumn{2}{c}{ Sig } \\
\hline CRSI - Positive problem solving & 1.03 & 10.205 & .285 & -.174 \\
CRSI - Conflict engagement & -.678 & -6.041 & -.144 & $p<.001$ \\
CRSI - Withdrawal & -.550 & -5.055 & -.106 & $p<.001$ \\
CRSI - Compliance & -.448 & -4.175 & -.140 & $p<.001$ \\
Financial issues & -1.28 & -5.020 & -.135 & $p<.001$ \\
Domestic chores & -1.02 & -4.848 & -.070 & $p=.007$ \\
Time spent together & -.375 & -2.695 & & \\
$R=.622 \quad$ Adjusted $R 2=.382$ & & &
\end{tabular}

\section{Discussion}

Although the measurement and understanding of the factors involved in marital quality remains a complex process, the present study aimed to assess the predictive power of themes of marital conflict and conflict resolution styles on marital quality in a sample of men and women from the South of Brazil.

The results demonstrate that the reason for conflict "time spent together" was the most frequently mentioned by the participants, followed by "children" and "household chores". These findings corroborate the Brazilian literature (Costa et al., 2015), which indicates lack of time spent together as a cause of distress in couples. On the other hand, considering the sample's socioeconomic and cultural level, attention is drawn to the fact that financial issues are not a frequent cause of conflict. However, the results show that discussions regarding money, domestic chores and the time the couples spent together appeared to have a negative impact on marital quality. These results are corroborated by the literature regarding the impact that the discussions about financial issues have on marital quality, since they are more stressful, threatening, long-drawn, recurring and difficult to resolve, and more likely to lead to increased anger and depression when compared to discussions regarding other topics (Papp et al., 2009).

As for the time spent together, although leisure activities are commonly cited as a reason for conflict in the Brazilian and international literature (Costa et al., 2015; Papp et al., 2009), this result is unexpected, because common sense understands this as a less conflicting topic for couples. Therefore, these data suggest that certain issues of modern society, such as the need to reconcile family and work, have an impact on marriage (Papp et al., 2009). The search for stability and individual/marital well-being must compete with the demands of work, which may lead individuals to focus on their own private issues rather than on their relationships. This strategy may consist in an attempt to avoid the complexity of marital conflicts, the resolution of which requires high degrees of sharing and cooperation, especially when dealing with delicate issues, such as financial aspects, daily life and time spent together. This may be the case for $80 \%$ of the present sample, who reported working outside their homes for an average of 8.6 hours a day $(S D=2.2$ hours).

However, even for individuals with an active work life, the ability to find the time to discuss problems and interpersonal differences with their partner, seeking solutions which benefit both parties in the relationship, may bring important benefits to marital quality (Askari et al., 2012). This is corroborated by the fact that, of all the factors studied, positive problemsolving strategies had the greatest positive association and predictive relationship with marital quality. These strategies underscore the importance of considering the needs of one's partner when facing and solving daily problems. The present findings suggest that these abilities are essential for a successful marriage, and that their development must be encouraged in couples who have difficulties with conflict resolution.

Couples in conflict often feel like they have too many problems and need to change many aspects of their lives to improve their relationships. However, our findings suggest that significant gains in marital satisfaction may be achieved simply by relying more heavily on communication and empathy when dealing with marital disputes, since these skills are part of a positive conflict resolution style. Therefore, a greater focus on the development of these abilities may be an 
Wagner, A., Mosmann, C. P., Scheeren, P., \& Levandowski, D. C. (2019). Marriage and Conflict Resolution.

important component of interventions for couples in conflict (Scheeren et al., 2014). Moreover, this knowledge can be used by professionals in the clinical care especially, but not only of couples, and psychotherapists can help their individual patients with marital conflicts to improve these conflict resolution abilities.

The results are in line with those of other investigations, which have reported that both the reasons for marital conflicts and the strategies used to address these issues may contribute significantly to the improvement of marital life (Birditt et al., 2010; Norgren et al., 2004; Ridley et al., 2001). Therefore, all of these variables must be considered when planning preventive and clinical interventions for couples with conflict issues. These variables are important seeing as this study was able to associate the reasons for marital conflict and the resolution strategies used to manage such disputes in a regression model which explained $38.7 \%$ of the variance in the marital quality reported.

Conflict resolution strategies were found to have both positive and negative effects on marital quality, illustrating the complex nature of marital relationships and the need for partners to alternate between different conflict resolution styles, depending on the reasons for each conflict, the time and context in which they occur, and the life cycle stage the couple finds itself in (McNulty \& Russell, 2010; Mosmann et al., 2006). For instance, although compliance and withdrawal are considered inadequate problem-solving strategies and are thought to have a negative impact on marital quality (Papp et al., 2007), they may at times play a protective role against the escalade of aggressive interactions, which could lead to extreme levels of violent behavior. In these cases, withdrawal may be more productive and protective for some couples than more active strategies, such as personal attacks or insults.

However, our results also showed that the predominance of positive approaches to problem solving over negative strategies and personal attacks may have a positive effect on marital quality, corroborating the results of previous studies (Birditt et al., 2010). Thus, the findings also revealed similarities between the characteristics of marital conflict and the resolution strategies employed by couples in Southern Brazil and in other cultures, such as those of Iran and North America (Askari et al., 2012; Birditt et al., 2010). These results have important implications for couple and family therapists, who are often concerned with the applicability of international research in different socioeconomic and cultural contexts. The similarity between the reasons for marital conflicts, the resolution strategies and the marital quality levels reported by the couples in different cultures may also suggest that economic globalization might have reduced or minimized the differences between affective relationships in different countries.

Also, it is important to note that, although these findings corroborate the international studies on marital relationships, they were obtained from a sample recruited in the South of Brazil, and must be interpreted within the socioeconomic and cultural context of this region and country. Most participants had a full-time employment, children and low to middle socioeconomic and cultural levels, which may have influenced the present results. The implications of these findings for clinical practice and for public domestic violence policies should also be interpreted in light of these characteristics.

Although the present study has increased the understanding of marital functioning regarding conflict reasons and resolution styles and their impact on marital quality, some limitations can be described. The data were not collected from a random sample and the data analysis model did not consider the respondents as couples. Future studies in Brazil should involve the qualitative assessment of the reasons for the conflicts reported and of the resolution strategies used by the participants, so as to better reflect the individual characteristics of each couple, and evaluate their association with the life cycle stage the couples find themselves in. Such investigations, together with the present results, could contribute to the development of more adequate instruments for assessment and improvement of marital quality in the Brazilian population.

In summary, our results show the importance of enhancing positive conflict resolution skills, and of considering the reasons for marital conflict and their emotional impact when addressing marital conflict in a clinical or psychotherapeutic setting. Topics associated with intense negative emotions need to be addressed simultaneously to the development of conflict resolution skills, since focusing on the latter alone may not be sufficiently effective to improve marital quality.

\section{References}

Askari, M., Noah, S. B. M., Hassan, S. A. B., \& Baba, M. B. (2012). Comparison the effects of communication and conflict resolution skills training on marital satisfaction. International Journal of Psychological Studies, 4(1), 182-195. doi:10.5539/ijps.v4n1p182

Ben-Naim, S., Hirschberger, G., Ein-Dor, T., \& Mikulincer, M. (2013). An experimental study of emotion regulation during relationship conflict interactions: The moderating role of attachment orientations. Emotion, 13(3), 506-519. doi:10.1037/a0031473

Birditt, K. S., Brown, E., Orbuch, T. L., \& Mcllvane, J. M. (2010). Marital conflict behaviors and implications for divorce over 16 years. Journal of Marriage and Family, 72(5), 1188-1204. doi:10.1111/j.1741-3737.2010.00758.x

Buehler, C., \& Gerard, J. M. (2002). Marital conflict, ineffective parenting, and children's and adolescents' maladjustment. Journal of Marriage and Family, 64(1), 78-93. doi:10.1111/j.1741-3737.2002.00078.x

Colossi, P. M., \& Falcke, D. (2013). Gritos do silêncio: A violência psicológica no casal [Screams of silence: Psychological violence in the couple]. Psico, 44(3), 310-318. Retrieved from http://revistaseletronicas.pucrs. br/ojs/index.php/revistapsico/article/view/11032/10404 doi:10.9788/TP2016.1-22 
Costa, C. B., Falcke, D., \& Mosmann, C. P. (2015). Conflitos conjugais em casamentos de longa duração: Motivos e sentimentos [Marital conflicts in long-term marriages: Motives and feelings]. Psicologia em Estudo, 20(3), 411-423. doi:10.4025/psicolestud.v20i3.2781

Delatorre, M. Z., Scheeren, P., \& Wagner, A. (2017). Conflito conjugal: Evidência de validade de uma escala de resolução de conflitos em casais do sul do Brasil [Marital conflict: Evidences of validity of a conflict resolution scale in couples in southern Brazil]. Avances en Psicología Latinoamericana, 35(1), 79-94. doi:10.12804/revistas.urosario.edu.co/apl/a.3742

Dong, M. C., \& Li, S. Y. (2007). Conflict resolution in Chinese family purchase decisions: The impact of changing female roles and marriage duration. International Journal of Conflict Management, 18(4), 308-324. doi:10.1108/10444060710833441

Dush, C. M. K., \& Taylor, M. G. (2012). Trajectories of marital conflict across the life course: Predictors and interactions with marital happiness trajectories. Journal of Family Issues, 33(3), 341-368. doi:10.1177/0192513X11409684

Falcke,D.,Wagner,A.,\&Mosmann,C.P.(2008).Therelationship between family-of-origin and marital adjustment for couples in Brazil. Journal of Family Psychotherapy, 19(2), 170-186. doi:10.1080/08975350801905020

Gottman, J. M. (1994). Why marriages succeed or fail. New York, NY: Simon \& Schuster.

Graber, E. C., Laurenceau, J. P., Miga, E., Chango, J., \& Coan, J. (2011). Conflict and love: Predicting newlywed marital outcomes from two interaction contexts. Journal of Family Psychology, 25(4), 541-550. doi:10.1037/a0024507

Johnson, M. D., Cohan, C. L., Davila, J., Lawrence, E., Rogge, R. D., Karney, B. R., . . Bradbury, T. N. (2005). Problem-solving skills and affective expressions as predictors of change in marital satisfaction. Journal of Consulting and Clinical Psychology, 73(1), 15-27. doi:10.1037/0022-006X.73.1.15

Kiecolt-Glaser, J. K., Gouin, J. P., \& Hantsoo, L. (2010). Close relationships, inflammation, and health. Neuroscience and Biobehavioral Reviews, 35(1), 33-38. doi:10.1016/j.neubiorev.2009.09.003

Kiecolt-Glaser, J. K., Jaremka, L., Andridge, R., Peng, J., Habash, D., Fagundes, C. P., . . . Belury, M. A. (2015). Marital discord, past depression, and metabolic responses to high-fat meals: Interpersonal pathways to obesity. Psychoneuroendocrinology, 52, 239-250. doi:10.1016/j.psyneuen.2014.11.018

Kurdek, L. A. (1994a). Areas of conflict for gay, lesbian, and heterosexual couples: What couples argue about influences relationship satisfaction. Journal of Marriage and Family, 56(4), 923-934. doi:10.2307/353603
Kurdek, L. A. (1994b). Conflict resolution styles in gay, lesbian, heterosexual nonparent, and heterosexual parent couples. Journal of Marriage and Family, 56(3), 705-722. doi:10.2307/352880

Leggett, D. G., Roberts-Pittman, B., Byczek, S., \& Morse, D. T. (2012). Cooperation, conflict, and marital satisfaction: Bridging theory, research, and practice. The Journal of Individual Psychology, 68(2), 182-199.

McNulty, J. K., \& Russell, V. M. (2010). When "negative" behaviors are positive: A contextual analysis of the long-term effects of problem-solving behaviors on changes in relationship satisfaction. Journal of Personality and Social Psychology, 98(4), 587-604. doi:10.1037/a0017479

Mosmann, C., \& Wagner, A. (2008). Dimensiones de la conyugalidad y de la parentalidad: Un modelo correlacional [Dimensions of marital relationship and parenting:Acorrelational model]. Revista Intercontinental de Psicología y Educación, 10(2), 79-103. Retrieved from http://www.redalyc.org/pdf/802/80212387005.pdf

Mosmann, C., Wagner, A., \& Féres-Carneiro, T. (2006). Qualidade conjugal: Mapeando conceitos [Marital quality: Mapping out concepts]. Paidéia (Ribeirão Preto), 16(35), 315-325. doi:10.1590/S0103-863X2006000300003

Norgren, M. B. P., Souza, R. M., Kaslow, F., Hammerschmidt, H., \& Sharlin, S. A. (2004). Satisfação conjugal em casamentos de longa duração: Uma construção possível [Marital satisfaction in long lasting marriages: A feasible construction]. Estudos de Psicologia (Campinas), 9(3), 575-584. doi:10.1590/S1413-294X2004000300020

Olson, D. H. (2000). Circumplex model of marital and family systems. Journal of Family Therapy, 22, 144-167.

Papp, L. M., Cummings, E. M., \& Goeke-Morey, M. C. (2009). For richer, for poorer: Money as a topic of marital conflict in the home. Family Relations, 58(1), 91-103. doi:10.1111/j.1741-3729.2008.00537.x

Papp, L. M., Goeke-Morey, M. C., \& Cummings, E. M. (2007). Linkages between spouses' psychological distress and marital conflict in the home. Journal of Family Psychology, 21(3), 533-537. doi: 10.1037/0893-3200.21.3.533

Papp, L. M., Goeke-Morey, M. C., \& Cummings, E. M. (2013). Let's talk about sex: A diary investigation of couples' intimacy conflicts in the home. Couple and Family Psychology: Research and Practice, 2(1), 60-72. doi:10.1037/a0031465

Rauer, A., Williams, L., \& Jensen, J. (2015). Finer distinctions: Variability in satisfied older couples' problem-solving behaviors. Family Process, 56(2), 501-517. doi: 10.1111/famp. 12198 
Rehman, U. S., Janssen, E., Newhouse, S., Heiman, J., Holtzworth-Munroe, A., Fallis, E., \& Rafaeli, E. (2011). Marital satisfaction and communication behaviors during sexual and nonsexual conflict discussions in newlywed couples: A pilot study. Journal of Sex \& Marital Therapy, 37(2), 94-103. doi:10.1080/0092623X.2011.547352

Ridley, C. A., Wilhelm, M. S., \& Surra, C. A. (2001). Married couples' conflict responses and marital quality. Journal of Social and Personal Relationships, 18(4), 517-534. doi:10.1177/0265407501184005

Rust, J., Bennun, I., Crowe, M., \& Golombok, S. (1988). The Golombok Rust Inventory of Marital State. Windsor, United Kingdom: NFER-NELSON.

Rust, J., Bennun, I., Crowe, M., \& Golombok, S. (2010). The Golombok Rust Inventory of Marital State (GRIMS). Sexual and Relationship Therapy, 25(1), 48-53. doi:10.1080/14681990903550183

Scheeren, P., Vieira, R. V. A., Goulart, V. R., \& Wagner, A. (2014). Marital quality and attachment: The mediator role of conflict resolution styles. Paidéia (Ribeirão Preto), 24(58), 177-186. doi:10.1590/1982-43272458201405

Scorsolini-Comin, F., Fontaine, A. M. G. V., Barroso, S. M., \& Santos, M. A. (2016). Fatores associados ao bemestar subjetivo em pessoas casadas e solteiras [Factors associated with the subjective well-being in married and unmarried people]. Estudos de Psicologia (Campinas), 33(2), 313-324. doi:10.1590/1982-02752016000200013

Sierau, S., \& Herzberg, P. Y. (2012). Conflict resolution as a dyadic mediator: Considering the partner perspective on conflict resolution. European Journal of Personality, 26(3), 221-232. doi:10.1002/per.828

Stroud, C. B., Meyers, K. M., Wilson, S., \& Durbin, C. E. (2015). Marital quality spillover and young children's adjustment: Evidence for dyadic and triadic parenting as mechanisms. Journal of Clinical Child \& Adolescent Psychology, 44(5), 800-813. doi: 10.1080/15374416.2014.900720

Veldorale-Brogan, A., Lambert, N. M., Fincham, F. D., \& DeWall, C. N. (2013). The virtue of problem-solving: Perceived partner virtues as predictors of problemsolving efficacy. Personal Relationships, 20(3), 511-523. doi:10.1111/j.1475-6811.2012.01421.x

Whisman, M. A., Dementyeva, A., Baucom, D. H., \& Bulik, C. M. (2012). Marital functioning and binge eating disorder in married women. International Journal of Eating Disorders, 45(3), 385-389. doi:10.1002/eat.20935

Williamson, H. C., Hanna, M. A., Lavner, J. A., Bradbury, T. N., \& Karney, B. R. (2013). Discussion topic and observed behavior in couples' problem-solving conversations: Do problem severity and topic choice matter? Journal of Family Psychology, 27(2), 330-335. doi:10.1037/a0031534
Adriana Wagner is a Professor at Universidade Federal do Rio Grande do Sul in the Programa de Pós-Graduação em Psicologia of Instituto de Psicologia, Porto Alegre-RS, Brazil.

Clarisse Pereira Mosmann is a Professor at the Programa de Pós-Graduação and the Curso de Psicologia of Universidade do Vale do Rio dos Sinos, São Leopoldo-RS, Brazil.

Patricia Scheeren is a Professor at Faculdade INEDI-CESUCA, Cachoeirinha-RS, Brazil.

Daniela Centenaro Levandowski is a Professor at Universidade Federal de Ciências da Saúde de Porto Alegre in the Programa de Pós-Graduação em Psicologia e Saúde e em Ciências da Saúde, Porto Alegre-RS, Brazil.

\section{Authors' Contribution:}

All authors made substantial contributions to the conception and design of this study, to data analysis and interpretation, and to the manuscript's revision and approval of the final version. All the authors assume public responsibility for the manuscript's contents.

Received: Jan. 24, 2017

1st Revision: Sep. 28, 2017

2nd Revision: Dec. 22, 2017

Approved: Feb. 12, 2018

How to cite this article:

Wagner, A., Mosmann, C. P., Scheeren, P., \& Levandowski, D. C. (2019). Conflict, conflict resolution and marital quality. Paidéia (Ribeirão Preto), 29, e2019. doi:http://dx.doi.org/10.1590/1982-4327e2919 